\title{
Melnick-Fraser Syndrome
}

National Cancer Institute

\section{Source}

National Cancer Institute. Melnick-Fraser Syndrome. NCI Thesaurus. Code C98983.

An autosomal dominant inherited syndrome caused by mutations in the EYA1, SIX1, and SIX5 genes. It is characterized by the abnormal development of the second branchial arch, resulting in the formation of branchial cleft cysts and fistulae, hearing loss and ear malformations, and renal abnormalities. 